\title{
TingKat Kesiapan KaWasan Industri Teras-Mojosongo KABUPATEN BOYOLALI SEBAGAI KAWASAN GREEN INDUSTRY
}

\author{
GALUH SRI UNTARI ${ }^{1}$ \\ PROGRAM STUdi PERENCANAAN WILAYAH DAN KotA \\ FAKULTAS TEKNIK \\ UNIVERSITAS SEBELAS MARET, SURAKARTA \\ email : uuntarigaluh@gmail.com \\ ANA HARDIANA ${ }^{2}$ \\ Program STUdi PERENCANAAN WILAYAH DAN KotA \\ FAKULTAS TEKNIK \\ UnIVERSITAS SEBELAS MARET, SURAKARTA \\ RUFIA ANDISETYANA PUTRI \\ PROGRAM STUdi PERENCANAAN WILAYAH DAN KotA \\ FAKULTAS TEKNIK \\ UNIVERSITAS SEBELAS MARET, SURAKARTA
}

\begin{abstract}
The industrial sector is one of the leading sector in Boyolali. There are several industrial area in Boyolali, one of them is Teras-Mojosongo Industrial Area. TerasMojosongo Industrial Area has been designated as one of a national-scale industrial area by the Ministry of Industry which is planned to be completed at 2016. The development of industrial area can not be separated from the impact to it's environment. Green industry is a concept of industrial area development to face environmental challenge and global economic crisis. Therefore the concept of green industry should be applied in the development of TerasMojosongo Industrial Area. This concern has to increase industrial economic growth and preserve environment. The question on this research is to know the readiness of Teras-Mojosongo Indutsrial Area as green industry area seen from characteristic (1) green plan, (2) green process, (3) green management, and (4) green policy. This research is a quantitative research using scoring analysis technique. Based on the analysis, the result shown that the level of readiness of Teras-Mojosongo industrial area as green industry area is close to ready. Therefore some of green industry characteristics that need to beimproved, such as green management characteristic and green policy characteristic. In order to increase the whole readiness of the green industrial area ind Teras-Mojosongo Boyolali.
\end{abstract}

Keywords: Environment, Green City, Green Industry, Industrial Area, Readiness

\section{PENDAHULUAN}

Kota Hijau atau Green City merupakan kota yang ramah lingkungan. Ukuran dari ramah lingkungan yang dimaksud dapat berupa tingkat polusi dan emisi karbon, penggunaan energy dan air, kualitas air, volume sampah dan banyaknya daur ulang, prosentase ruang terbuka hijau, serta alih fungsi lahan pertanian
[Meadows, 1999; Brugmann,1999]. Kota Hijau memiliku 8 atribut meliputi Green Planning and Design, Green Open Space, Green Waste, Green Transportation, Green Water, Green Energy, Green Building, dan Green Community.

Konsep kota hijau terus mengalami perkembangan salah satunya adalah konsep Green Industry. Green industry 
muncul karena adanya keinginan manusia untuk meningkatkan pertumbuhan ekonomi namun tetap memperhatikan kelestarian lingkungan.

Menurut Peraturan Menteri Perindustrian Nomor 05/M-IND/PER/1/201l tentang Program Penganugrahan Penghargaaan Industri Hijau, yang dimaksud dengan Industri Hijau (Green Industry) merupakan industri berwawasan lingkungan yang menyelaraskan pertumbuhan dengan kelestarian lingkungan hidup mengutamakan efisiensi dan efektivitas penggunaan sumber daya alam serta bermanfaat bagi masyarakat.

Industri sendiri merupakan sektor cepat tumbuh dalam perekonomian Indonesia. Selain itu, industri juga merupakan sektor dengan penggunaan sumber daya dan energy terbesar dan penghasil limbah dalam jumlah banyak. Maka dari itu, Kementrian Perindustrian memilih konsep green industry sebagai konsep wajib dalam pengembangan kawasan industri di Indonesia [Kemenperin, 2012]. Kecamatan Teras-Mojosongo merupakan kawasan industri yang ditetapkan Pemerintah Boyolali melalui Rencana Tata Ruang Wilayah Kabupaten Boyolali tahun 2011-2031. Kawasan ini juga telah ditunjuk oleh Kementrian Perindustrian sebagai salah satu dari sembilan kawasan industri berskala nasional yang direncanakan penyusunan masterplannya selesai pada tahun 2016 . Pengembangan kawasan industri ini direncanakan untuk menggunakan konsep kawasan green industry [Kemenperin, 2015].

Untuk mendukung konsep besar pengembangan investasi Kabupaten Boyolali, yaitu Boyolali Green City, Boyolali Water City, dan Boyolali Smart City, Pemerintah Kabupaten Boyolali juga menerapkan konsep Green Industry dalam pengembangan kawasan industrinya (Pemkab Boyolali, 2011).

Belum tersedianya beberapa infrastruktur pendukung kawasan khususnya akses untuk mobilisasi kegiatan industri serta jaringan pengolahan limbah, perlu menjadi perhatian khusus Pemerintah Kabupaten Boyolali dalam mengembangkan Kawasan Green Industry. Hal penting lainnya yang belum dipenuhi oleh Kawasan Green Industry ini adalah belum adanya manajemen khusus yang mengelola kawasan sehingga mampu melakukan manajemen dan kontroling terhadap kawasan.

Melihat fakta-fakta di kawasan industri Teras-Mojosongo tersebut dapat dirumuskan pertanyaan penelitian "Bagaimana tingkat kesiapan kawasan industri Kecamatan Teras-Mojosongo Kabupaten Boyolali sebagai kawasan green industry?"

\section{TINJAUAN PUSTAKA}

\subsection{Kesiapan}

Kesiapan terjadi jika ada ketuntasan dalam rencana, ada kecukupan dan latihan dari pelaku, serta ketersediaan dukungan pelayanan atau system (Business Dictionary, 2016). Maka, terdapat 3 hal yang harus dilakukan untuk mewujudkan kesiapan:

a. Ketuntasan, terkait rencana

b. Kecukupan, mampu memenuhi kebutuhan

c. Ketersediaan, berarti sudah ada

\subsection{Green City}

Kota Hijau atau Green City dapat diukur melalui tingkat polusi dan emisi karbon, penggunaan energi dan air, kualitas air, volume sampah dan banyaknya daur ulang, prosentase ruang terbuka hijau, serta alih fungsi lahan pertanian [Meadows \& Brugmann, 1999]. Salah satu upaya yang dapat dilakukan adalah dengan membangun kota lestari atau kota hijau yang didukung jaringan infrastruktur hijau, termasuk hutan-hutan kota, sebagai penyangga kehidupan kota. Kota Hijau memiliki 8 atribut, 
meliputi Green Planning and Design, Green Open Space, Green Waste, Green Transportation, Green Water, Green Energy, Green Building, dan Green Community [Joga, 2013].

Kota Hijau merupakan kota yang memanfaatkan air dan energi secara efektif dan efisien; mengurangi produksi limbah; menerapkan sistem transportasi terpadu; menjamin kesehatan lingkungan; mensinergikan lingkungan alami dan buatan; berdasarkan perencanaan kota yang berpihak pada prinsip-prinsip pembangunan berkelanjutan [Kementrian Pekerjaan Umum, 2011]. Kota hijau cenderung mempertahankan lahan terbuka yang ada dan membatasi pembangunan fisik sebagai upaya dalam menyeimbangkan kondisi lingkungan. Pembangunan yang dilakukan dalam kota hijau lebih terfokus pada pengembangan kualitas lingkungan serta pembangunan infrastruktur yang ramah lingkungan.

Berdasarkan teori yang ada dilakukan sintesa, sehingga didapat sintesa komponen green city, meliputi Green Energy, Green Water, Green Waste, Green Open Space, Green Transportation, Green Planning an Design, dan Green Community [Meadows \& Brugmann, 1999; Joga, 2013 Kementrian Pekerjaan Umum, 2011].

\subsection{Kawasan Industri}

Kawasan industri/Industrial Estate atau sering disebut juga Industrial Park merupakan kawasan yang dibangun pada suatu lahan dengan peruntukan sesuai untuk kegiatan ekonomi mengolah bahan baku/sumber daya industri sehingga memiliki nilai jual/nilai tambah yang lebih tinggi, baik dilihat dari lokasinya yang strategis maupun zoning kawasan yang tepat. Kawasan industri perlu didukung dengan ketersediaan infrastruktur (utilitas) yang memadai serta kemudahan dalam aksesibilitas trasportasi baik barang maupun manusia (tenaga kerja). Suatu kawasan industri biasanya dikelola secara administrative oleh perserangan atau lembaga terkait yang berwenang [Komite Nasional Kawasan Industri Amerika Serikat/National Industrian Zoning Committee's USA, 1975].

Kawasan industri merupakan suatu daerah atau kawasan yang didominasi oleh aktivitas industri. Kawasan industri biasanya dilengkapi oleh berbagai fasilitas pendukung kegiatan industri didalamnya, seperti peralatan-peralatan pabrik (industrial plants), laboratorium untuk pengembangan industri, bangunan perkantoran industri, bank, serta prasarana umum lainnya mencangkup perumahan, sekolah, tempat ibadah, ruang terbuka hijau, dll [ULI, 1975].

Berdasarkan teori yang ada dilakukan sintesa sehingga didapat sintesa komponen Kawasan Industri, meliputi Lahan Kawasan Industri, Infrastruktur Kawasan Industri, Manajemen Pengelola Kawasan Industri, dan Kebijakan Kawasan Industri [Komite Nasional Kawasan Industri Amerika Serikat/National Industrian Zoning Committee's USA, 1975; ULI, 1975].

\subsection{Green Industry}

Green Industry merupakan salah satu akibat dari adanya usaha konservasi dan perlindungan terhadap lingkungan (Zhang, 2016). Penerapan konsep Green Industry bertujuan untuk memperbaiki kondisi lingkungan, mempromosikan kestabilan pembangunan ekonomi, menciptakan lapangan kerja pagi masyarakat, efisiensi energi, serta menciptakan masyarakat yang peduli terhadap lingkungan [Lu S., 2013].

Berdasarkan teori yang ada dilakukan sintesa sehingga didapat sintesa green industry, meliputi Green Plan, Green Process, Keterlibatan Masyarakat dan 
Ketersediaan Dokumen Lingkungan [Zhang, 2016; Lu S., 2013]

\section{METODE PENELITIAN}

Penelitian ini bertujuan untuk mengetahui tingkat kesiapan kawasan industri Kecamatan Teras-Mojosongo Kabupaten Boyolali sebagai kawasan green industry. Ditinjau dari variabel komponen kawasan green industry dan analisis skoring tingkat kesiapan kawasan industri Teras-Mojosongo sebagai kawasan green industry dengan variabel penelitian dan teknik analisis sebagai berikut:

\subsection{Variabel Penelitian}

Variabel dalam penelitian ini ada empat yaitu green plan, green process, green management, dan green policy. Dengan definisi sebagai berikut:

Tabel 1. Definisi Variabel Kawasan Green Industry

\begin{tabular}{|c|c|c|}
\hline No & Variabel & Definisi \\
\hline 1 & Green plan & $\begin{array}{l}\text { Green plan merupakan rencana } \\
\text { kawasan yang berpedoman } \\
\text { pada konsep ramah lingkungan } \\
\text { (Yongli Zhang, 2016), yang } \\
\text { mencangkup } 3 \text { aspek penting } \\
\text { green city: } \\
\text { 1. Rencana pengembangan } \\
\text { kawasan industri hijau } \\
\text { 2. Rencana pengembangan } \\
\text { kawasan infrastruktur } \\
\text { lingkungan hijau pengembangan } \\
\text { 3. Rencana komunitas } \\
\text { kawasan pasanat) hijau } \\
\text { (masayrakan }\end{array}$ \\
\hline 2 & Green process & $\begin{array}{l}\text { Green prosses merupakan hal- } \\
\text { hal yang mendukung } \\
\text { terwujudnya konsep ramah } \\
\text { lingkungan dalam industry } \\
\text { manufactur (Lu Yong-Long, dkk: } \\
\text { 2015). Termasuk di dalamnya: } \\
\text { 1. Lahan penunjang green } \\
\text { industry } \\
\text { 2. Sarana penunjang green } \\
\text { industry } \\
\text { 3. Prasarana penunjang green } \\
\text { industry } \\
\text { 4. Transportasi penunjang } \\
\text { green industry }\end{array}$ \\
\hline 3 & $\begin{array}{l}\text { Green } \\
\text { management }\end{array}$ & $\begin{array}{l}\text { Green management, meliputi: } \\
\text { 1. Pengelola kawasan industri } \\
\text { 2. } \\
\text { Masyarakat sekitar kawasan } \\
\text { industri dalam bentuk CSR } \\
\text { Hijau }\end{array}$ \\
\hline 4 & Green policy & $\begin{array}{l}\text { Green policy merupakan payung } \\
\text { hukum kawasan green industry, } \\
\text { yang meliputi: }\end{array}$ \\
\hline
\end{tabular}

\begin{tabular}{|c|c|ll|}
\hline No & Variabel & \multicolumn{1}{|c|}{ Definisi } \\
\hline & & 1. & Dokumen ijin lingkungan \\
& & 2. & $\begin{array}{l}\text { Peraturan } \\
\text { undangan }\end{array}$ \\
\hline
\end{tabular}

Sumber : UNIDO (2010); Zhang Wei, Jin Yuguo, dan Wang Jiaping (2014); Lu S., Huang M., Su P., Tseng., Chen (2013); Yongli Zhang (2016); Kementrian Perindustrian (2011); RIPIN (2015-2035) dan Penulis (2017)

\subsection{Teknik Analisis}

\subsubsection{Identifikasi}

Karakteristik Kawasan Industri Teras-Mojosongo berdasarkan Komponen Kawasan Green Industri

Analisis yang dilakukan dengan teknik analisis skoring bertingkat ini ada beberapa tahapan. Tahap yang pertama adalah dilakukan penilaian kesiapan karakteristik kawasan industri TerasMojosongo pada tahap parameter sesuai table lampiran 1. Tahap kedua dilakukan penilaian kesiapan pada tingkat subvariabel dengan rumus sebagai berikut: interval $=\frac{(\text { total skor tertinggi })-(\text { total skor terendah })}{\text { jumlah } k \text { elas }}$

Tabel 2. Interval Skoring Sub-variabel

\begin{tabular}{|c|c|c|}
\hline \multirow{2}{*}{ Subvariabel } & \multicolumn{2}{|c|}{ Skor } \\
\hline & Siap (2) & Tidak Siap (1) \\
\hline $\begin{array}{l}\text { Rencana } \\
\text { pengembangan } \\
\text { industri hijau } \\
\text { (terdiri dari } 3 \\
\text { parameter) }\end{array}$ & $\begin{array}{l}\text { Jika hasil skoring } \\
\text { dari seluruh } \\
\text { parameter } \\
\text { rencana } \\
\text { pengembangan } \\
\text { industri hijau } \\
\text { adalah 4,6-6 }\end{array}$ & $\begin{array}{l}\text { Jika hasil skoring } \\
\text { dari seluruh } \\
\text { parameter } \\
\text { rencana } \\
\text { pengembangan } \\
\text { industri hijau } \\
\text { adalah } 3-4,5\end{array}$ \\
\hline $\begin{array}{l}\text { Rencana } \\
\text { pengembangan } \\
\text { infrastruktur } \\
\text { lingkungan hijau } \\
\text { (terdiri dari } 11 \\
\text { parameter) }\end{array}$ & $\begin{array}{l}\text { Jika hasil skoring } \\
\text { dari seluruh } \\
\text { parameter } \\
\text { rencana } \\
\text { pengembangan } \\
\text { infrastruktur } \\
\text { lingkungan hijau } \\
\text { adalah } 16,6-22\end{array}$ & $\begin{array}{l}\text { Jika hasil skoring } \\
\text { dari seluruh } \\
\text { parameter } \\
\text { rencana } \\
\text { pengembangan } \\
\text { infrastruktur } \\
\text { lingkungan hijau } \\
\text { adalah } 11-16,5\end{array}$ \\
\hline $\begin{array}{l}\text { Rencana } \\
\text { pengembangan } \\
\text { komunitas/masayr } \\
\text { akat hijau (terdiri } \\
\text { dari } 2 \text { parameter) }\end{array}$ & $\begin{array}{l}\text { Jika hasil skoring } \\
\text { dari seluruh } \\
\text { parameter } \\
\text { rencana } \\
\text { pengembangan } \\
\text { komunitas/masyr } \\
\text { akat hijau adalah } \\
3,1-4\end{array}$ & $\begin{array}{l}\text { Jika hasil skoring } \\
\text { dari seluruh } \\
\text { parameter } \\
\text { rencana } \\
\text { pengembangan } \\
\text { komunitas/masyr } \\
\text { akat hijau adalah } \\
2-3\end{array}$ \\
\hline $\begin{array}{l}\text { Lahan industri } \\
\text { (terdiri dari } 2 \\
\text { parameter) }\end{array}$ & $\begin{array}{l}\text { Jika hasil skoring } \\
\text { dari } \\
\text { parameter lahan } \\
\text { industri adalah } \\
3,1-4\end{array}$ & $\begin{array}{l}\text { Jika hasil skoring } \\
\text { dari seluruh } \\
\text { parameter lahan } \\
\text { industri adalah 2- } \\
3\end{array}$ \\
\hline $\begin{array}{l}\text { Sarana penunjang } \\
\text { industri (terdiri } \\
\text { dari } 5 \text { parameter) }\end{array}$ & $\begin{array}{l}\text { Jika hasil skoring } \\
\text { dari seluruh } \\
\text { parameter sarana } \\
\text { penunjang } \\
\text { industri adalah } \\
7,6-10\end{array}$ & $\begin{array}{l}\text { Jika hasil skoring } \\
\text { dari seluruh } \\
\text { parameter sarana } \\
\text { penunjang } \\
\text { industri adalah 5- } \\
7,5\end{array}$ \\
\hline $\begin{array}{l}\text { Prasarana } \\
\text { penunjang } \\
\text { industri (terdiri } \\
\text { dari } 4 \text { parameter) }\end{array}$ & $\begin{array}{l}\text { Jika hasil skoring } \\
\text { dari seluruh } \\
\text { parameter } \\
\text { prasarana }\end{array}$ & $\begin{array}{l}\text { Jika hasil skoring } \\
\text { dari seluruh } \\
\text { parameter } \\
\text { prasarana }\end{array}$ \\
\hline
\end{tabular}


Galuh Sri Untari dkk, Tingkat Kesiapan Kawasan Industri...

\begin{tabular}{|c|c|c|}
\hline \multirow{2}{*}{ Subvariabel } & \multicolumn{2}{|c|}{ Skor } \\
\hline & Siap (2) & Tidak Siap (1) \\
\hline & $\begin{array}{l}\text { penunjang } \\
\text { industri adalah } \\
6,1-8\end{array}$ & $\begin{array}{l}\text { penunjang } \\
\text { industri adalah 4- } \\
6\end{array}$ \\
\hline $\begin{array}{l}\text { Transportasi } \\
\text { penunjang } \\
\text { industri (terdiri } \\
\text { dari } 2 \text { parameter) }\end{array}$ & $\begin{array}{l}\text { Jika hasil skoring } \\
\text { dari seluruh } \\
\text { parameter } \\
\text { transportasi } \\
\text { penunjang } \\
\text { industri adalah } \\
3,1-4\end{array}$ & $\begin{array}{l}\text { Jika hasil skoring } \\
\text { dari seluruh } \\
\text { parameter } \\
\text { transportasi } \\
\text { penunjang } \\
\text { industri adalah 2- } \\
3\end{array}$ \\
\hline $\begin{array}{l}\text { Manajemen } \\
\text { pengelola } \\
\text { kawasan (terdiri } \\
\text { dari l parameter) }\end{array}$ & $\begin{array}{l}\text { Jika hasil skoring } \\
\text { dari parameter } \\
\text { manajemen } \\
\text { pengelola } \\
\text { kawasan adalah } 2\end{array}$ & $\begin{array}{l}\text { Jika hasil skoring } \\
\text { dari parameter } \\
\text { manajemen } \\
\text { pengelola } \\
\text { kawasan adalah } 1\end{array}$ \\
\hline $\begin{array}{l}\text { CSR Hijau (terdiri } \\
\text { dari } 7 \text { parameter) }\end{array}$ & $\begin{array}{l}\text { Jika hasil skoring } \\
\text { dari seluruh } \\
\text { parameter CSR } \\
\text { Hijau adalah 10,6- } \\
14\end{array}$ & $\begin{array}{l}\text { Jika hasil skoring } \\
\text { dari parameter } \\
\text { CSR Hijau adalah } \\
7-10,5\end{array}$ \\
\hline $\begin{array}{l}\text { Dokumen } \\
\text { perijinan (terdiri } \\
\text { dari } 42 \text { parameter) }\end{array}$ & $\begin{array}{l}\text { Jika hasil skoring } \\
\text { dari seluruh } \\
\text { parameter } \\
\text { dokumen } \\
\text { perijinan adalah } \\
63,1-84\end{array}$ & $\begin{array}{l}\text { Jika hasil skoring } \\
\text { dari seluruh } \\
\text { parameter } \\
\text { dokumen } \\
\text { perijinan adalah } \\
42-63\end{array}$ \\
\hline $\begin{array}{l}\text { Peraturan } \\
\text { perundang- } \\
\text { undangan daerah } \\
\text { (terdiri dari } 3 \\
\text { parameter) }\end{array}$ & $\begin{array}{l}\text { Jika hasil skoring } \\
\text { dari seluruh } \\
\text { parameter } \\
\text { peraturan } \\
\text { perundang- } \\
\text { undnagan daerah } \\
\text { adalah 4,6-6 }\end{array}$ & $\begin{array}{l}\text { Jika hasil skoring } \\
\text { dari seluruh } \\
\text { parameter } \\
\text { peraturan } \\
\text { perundang- } \\
\text { undnagan daerah } \\
\text { adalah 3-4,5 }\end{array}$ \\
\hline
\end{tabular}

Tahap ketiga dilakukan penilaian kesiapan pada tingkat variabel dengan rumus sebagai berikut:

interval $=\frac{(\text { total skor tertinggi })-(\text { total skor terendah })}{\text { jumlah kelas }}$

Tabel 3. Interval Skoring Variabel

\begin{tabular}{|c|c|c|c|}
\hline \multirow{2}{*}{\multicolumn{2}{|c|}{ Variabel }} & \multicolumn{2}{|c|}{ Skor } \\
\hline & & Siap (2) & Tidak Siap (1) \\
\hline $\begin{array}{l}\text { Green plan } \\
\text { (terdiri dari } \\
\text { subvariabel) }\end{array}$ & 3 & $\begin{array}{l}\text { Jika hasil } \\
\text { dari } \\
\text { suboring } \\
\text { suriabel green } \\
\text { plan adalah } 4,6-6\end{array}$ & $\begin{array}{l}\text { Jika hasil skoring } \\
\text { dari seluruh } \\
\text { seluruh } \\
\text { subvariabel green } \\
\text { plan adalah } 3-4,5\end{array}$ \\
\hline $\begin{array}{l}\text { Green process } \\
\text { (terdiri dari } \\
\text { subvariabel) }\end{array}$ & 4 & $\begin{array}{l}\text { Jika hasil skoring } \\
\text { dari } \\
\text { subvariabel green } \\
\text { process adalah } \\
6,1-8\end{array}$ & $\begin{array}{l}\text { Jika hasil skoring } \\
\text { dari seluruh } \\
\text { subvariabel green } \\
\text { process adalah } 4- \\
6\end{array}$ \\
\hline $\begin{array}{l}\text { Green } \\
\text { management } \\
\text { (terdiri dari } \\
\text { subvariabel) }\end{array}$ & 2 & $\begin{array}{l}\text { Jika hasil skoring } \\
\text { dari seluruh } \\
\text { subvariabel green } \\
\text { management } \\
\text { adalah 3,1-4 }\end{array}$ & $\begin{array}{l}\text { Jika hasil skoring } \\
\text { dari seluruh } \\
\text { subvariabel green } \\
\text { management } \\
\text { adalah 2-3 }\end{array}$ \\
\hline $\begin{array}{l}\text { Green policy } \\
\text { (terdiri dari } \\
\text { subvariabel) }\end{array}$ & 2 & $\begin{array}{l}\text { Jika hasil } \\
\text { dari } \\
\text { daboring } \\
\text { subvariabel green } \\
\text { policy adalah } 3,1-4\end{array}$ & $\begin{array}{l}\text { Jika hasil skoring } \\
\text { dari seluruh } \\
\text { parameter lahan } \\
\text { industri adalah 2- } \\
3\end{array}$ \\
\hline
\end{tabular}

Sumber : Hasil Analisis, 2017

\subsubsection{Analisis Kesiapan Kawasan Industri Teras-Mojosongo sebagai Kawasan Green Industri}

Analisis yang dilakukan adalah dengan cara mengalikan skor kesiapan masingmasing variabel dengan bobot variabel penelitian.

Bobot variabel dihitung dengan teknik weighted product (WP). Teknik analisis yang digunakan adalah Weighted Product (WP). WP merupakan merupakan metode pengambilan keputusan multi kriteria dengan cara perkalian untuk menghubungkan rating alternatif, dimana rating alternatif harus dipangkatkan dulu dengan bobot alternatif yang bersangkutan [Basyaib, 2006].

Berdasarkan perhitungan yang dilakukan (lampiran 2.), maka didapat bobot masing-masing variabel sebagai berikut:

Tabel 4. Bobot Variabel Penelitian

\begin{tabular}{|l|c|}
\hline \multicolumn{1}{|c|}{ Variabel } & Bobot \\
\hline Green plan & 0,242 \\
\hline Green process & 0,258 \\
\hline Green management & 0,250 \\
\hline Green policy & 0,250 \\
\hline
\end{tabular}

Sumber : Hasil Analisis, 2017

Setelah diketahui nilai kesiapan, yaitu nilai total perkalian skoring variabel dan bobot variabel, dilakukan perhitungan presentase kesiapan dengan rumus sebagai berikut:

Presentase kesiapan $=\frac{\text { jumlah total nilai kesiapan }}{(\text { jumlah total nilai tertinggi })} \times 100 \%$

Selanjutnya presentase kesiapan akan dibagi kedalam 3 rentang kesiapan, yaitu mendekati tidak siap, mendekati siap dan tidak siap, serta mendekati siap. Hal ini adalah upaya interpretasi hasil analisis yang dapat dipaham secara relative berdasarkan hasil penelitian yang didapat, bukan secara mutlak. Untuk lebih jelasnya berikut rentang masingmasing klasifikasi kesiapan kawasan industri Teras-Mojosongo sebagai kawasan green industry [Sugiyono, 2007] 
a. Apabila presentase kesiapan termasuk rentang $0-49 \%$, maka kesiapan kawasan industri TerasMojosongo dinyatakan mendekati tidak siap untuk dikembangkan sebagai kawasan green industry Boyolali.

b. Apabila presentase kesiapan termasuk rentang 50\%, maka kesiapan kawasan industri Teras-Mojosongo dinyatakan mendekati siap dan tidak siap untuk dikembangkan sebagai kawasan green industry Boyolali.

c. Apabila presentase kesiapan termasuk rentang $51 \%-100 \%$, maka kesiapan kawasan industri TerasMojosongo dinyatakan mendekati siap untuk dikembangkan sebagai kawasan green industry Boyolali.

\section{HASIL DAN PEMBAHASAN}

Kawasan Green Industry TerasMojosongo merupakan Kawasan Industri di Kabupaten Boyolali yang dikembangkan dengan mengadaptasi konsep industri ramah lingkungan yaitu green industry. Kawasan ini sudah sesuai dengan peruntukan kawasan yang tertera dalam RTRW Boyolali 2011-2031. Kawasan green industry ini merupakan kawasan dengan radius 1 kilometer dari masing masing embrio industri di Kecamatan Teras dan Mojosongo Kabupaten Boyolali. Kawasan ini meliputi 2 kecamatan dan 12 desa, dengan luas keseluruhan kurang lebih 1742 hektar.

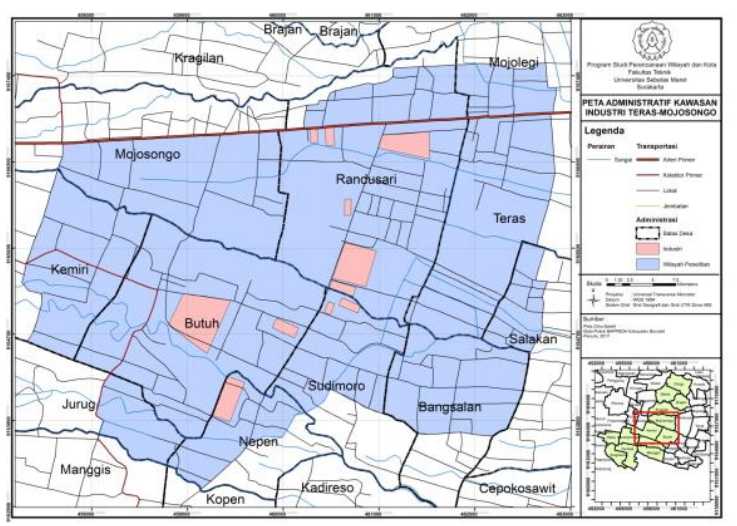

Gambar 1 Peta Administratif Kawasan Industri Teras-Mojosongo

\subsection{Kesiapan Karakteristik Kawasan Industri}

Karakteristik kawasan industri berdasarkan komponen kawasan green industry meliputi green plan, green process, green management, dan green policy. Green plan merupakan rencana pengembangan kawasan yang berpedoman pada konsep ramah lingkungan, dimana mencangkup rencana pengembangan kawasan industri hijau, rencana pengembangan infrastruktur hijau serta rencana pengembangan kawasan komunitas hijau. Green process merupakan hal-hal yang mendukung berlangsungnya kegiatan industri manufaktur namun tetap mengedepankan konsep ramah lingkungan, meliputi lahan penunjang industri hijau, sarana penunjang industri hijau, prasarana penunjang industri hijau, serta transportasi penunjang industri hijau. Green management merupakan upaya dari pengelola kawasan industri untuk menerapkan atribut green city dalam melaksanakan fungsi manajemen serta tanggung jawabnya baik terhadap masyarakat maupun keberlangsungan social melalui CSR Hijau. Sedangkan green policy merupakan payung hukum dan dasar penyelenggaraan segala kegiatan di dalam kawasan, sehingga keberadaannya merupakan keadaan mutlak bagi suatu kawasan.

Berdasarkan analisis yang telah dilakukan, didapatkan nilai untuk masing-masing kesiapan pada masingmasing variabel adalah sebagai berikut:

Tabel 5. Nilai Kesiapan Variabel Green Plan

\begin{tabular}{|l|c|c|}
\hline \multicolumn{1}{|c|}{ Sub-Variabel } & $\begin{array}{c}\text { Total } \\
\text { Nilai }\end{array}$ & Kesiapan \\
\hline $\begin{array}{l}\text { Rencana pengembangan } \\
\text { industri hijau }\end{array}$ & 6 & Siap (2) \\
\hline $\begin{array}{l}\text { Rencana pengembangan } \\
\text { infrastruktur hijau }\end{array}$ & 21 & Siap (2) \\
\hline $\begin{array}{l}\text { Rencana pengebangan } \\
\text { komunitas hijau }\end{array}$ & 4 & Siap (2) \\
\hline
\end{tabular}

Sumber : Analisis Peneliti, 2017 
Komponen Green Plan terkait penerapan konsep green industry pada kawasan industri Teras-Mojosongo termasuk dalam kategori siap. Hal ini terlihat dari sudah tersedianya rencana yang mengatur kegiatan industri hijau dikawasan, infrastruktur penunjang industri hijau maupun rencana yang mengatur pengembangan komunitas hijau di kawasan industri TerasMojosongo. Rencana tersebut tertuang dalam beberapa dokumen rencana kabupaten Boyolali dengan lokasi perencanaan merujuk pada kawasan industri Teras-Mojosongo. Rencana yang ada belum memang berbentuk satu dokumen rencana induk perindustrian/masterplan kawasan industri hijau sehingga belum mendetail hingga ke teknis pelaksanaannya pada kawasan industri Teras-Mojosongo.

Tabel 6. Nilai Kesiapan Variabel Green Process

\begin{tabular}{|l|c|c|}
\hline \multicolumn{1}{|c|}{ Sub-Variabel } & $\begin{array}{c}\text { Total } \\
\text { Nilai }\end{array}$ & Kesiapan \\
\hline $\begin{array}{l}\text { Lahan penunjang kawasan green } \\
\text { industry }\end{array}$ & 4 & Siap (2) \\
\hline $\begin{array}{l}\text { Sarana penunjang kawasan } \\
\text { green industry }\end{array}$ & 18 & Siap (2) \\
\hline $\begin{array}{l}\text { Prasarana penunjang kawasan } \\
\text { green industry }\end{array}$ & 8 & Siap (2) \\
\hline $\begin{array}{l}\text { Transportasi penunjang kawasan } \\
\text { green industry }\end{array}$ & 4 & Siap (2) \\
\hline
\end{tabular}

Sumber : Analisis Peneliti, 2017

Komponen green process pada kawasan industri Teras-Mojosongo sendiri berada pada kategori siap. Dimana dari kurang lebih 1700 Ha lahan yang ada, 52\% masih berupa lahan kosong sehingga masih dimungkinkan untuk melakukan pembangunan dengan tetap memperhatikan prosentase lahan ideal pada suatu kawasan. Sarana penunjang pada kawasan green industry juga sudah lengkap dan tersebar di seluruh kawasan industri Teras-Mojosongo sehingga memudahkan masyarakat maupun tenaga kerja kawasan dalam memenuhi kebutuhannya. Jaringan prasarana kawasan juga berusaha untuk mendukung konsep ramah lingkungan kawasan, misalnya adanya energi pengganti listrik dalam proses produksi serta penggunaan kembali air hasil pengolahan dalam proses produksi. Jaringan prasarana yang ada di kawasan menunjukan potensi kawasan dalam mencapai tujuan utama ekonomi hijau yakni meningkatkan kegiatan ekonomi (industri) dan mengurangi dampaknya terhadap sumber daya indutri dan lingkungan.

Dengan adanya pemanfaatan energi selain listrik dan air hasil pengolahan kembali berarti kawasan sudah mampu mengurangi/menghemat sumber daya industri dalam kegiatanya. Dan sebagai potensi dalam mengurangi dampak terhadap lingkungan, perusahaan industri berusaha melakukan pengolahan terhadap limbah industri, baik melalui sistem 3R maupun instalasi pengolahan (IPAL) sehingga tidak semua limbah industri dibuang ke lingkungan. Selain itu dari segi transportasi, beberapa kawasan telah berusaha mengurangi emisi akibat penggunaan kendaraan bermotor salah satunya dengan cara penggunaan mobil dan sepeda listrik (accu) walaupun penggunaannya masih terbatas pada internal perusahaan industri.

Tabel 7. Nilai Kesiapan Variabel Green Management

\begin{tabular}{|l|c|c|}
\hline \multicolumn{1}{|c|}{ Sub-Variabel } & $\begin{array}{c}\text { Total } \\
\text { Nilai }\end{array}$ & Kesiapan \\
\hline $\begin{array}{l}\text { Adanya pengelola khusus } \\
\text { kawasan green industry }\end{array}$ & 1 & Tidak siap (1) \\
\hline $\begin{array}{l}\text { Tersedia kegiatan CSR Hijau } \\
\text { yang melibatkan masyarakat } \\
\text { dengan tujuan utama pelestarian } \\
\text { lingkungan hidup }\end{array}$ & 14 & Siap (2) \\
\hline
\end{tabular}

Sumber : Analisis Peneliti, 2017

Kategori kesiapan komponen green management berdasarkan karakteristik kawasan industri Teras-Mojosongo termasuk kategori tidak siap dikarenakan belum ada manajemen pengelola yang bertugas/berwewenang dalam melakukan kegiatan pengelolaan kawasan industri Teras-Mojosongo. Dimana keberadaan manajemen pengelola yang khusus mengelola suatu kawasan industri memiliki peran penting dalam menyatukan berbagai kepentingan stakeholder terkait kawasan 
industri, sehingga pengembangan kawasan industri yang ada tidak merugikan stakeholder tertentu maupun lingkungan terkait penerapan konsep green industry (William Bredo, 1969). Kegiatan pengelolaan kawasan industri Teras-Mojosongo diatas kertas memang masih menjadi hak Pemerintah Kabupaten Boyolali, namun pada kenyataan dilapangan kegiatan pengelolaan dilakukan oleh masingmasing perusahaan industri. Pemerintah Kabupaten Boyolali bertugas mengontrol kegiatan masing-masing perusahaan industri di kawasan agar tetap sesuai dengan visi-misi perindustrian Kabupaten Boyolali

Tabel 7. Nilai Kesiapan Variabel Green Policy

\begin{tabular}{|l|c|c|}
\hline \multicolumn{1}{|c|}{ Sub-Variabel } & $\begin{array}{c}\text { Total } \\
\text { Nilai }\end{array}$ & Kesiapan \\
\hline $\begin{array}{l}\text { Green industry telah memiliki } \\
\text { ijin tata ruang, ijin gangguan, } \\
\text { IMB, dokumen lingkungan, ijin } \\
\text { pengolahan limbah, dan ijin } \\
\text { usaha }\end{array}$ & 84 & Siap (2) \\
\hline $\begin{array}{l}\text { Tersedianya peraturan daerah } \\
\text { serta peraturan/keputusan } \\
\text { kepala daerah kawasan green } \\
\text { industry terkait karakteristik } \\
\text { kawasan industri }\end{array}$ & 4 & Tidak siap (1) \\
\hline
\end{tabular}

Sumber : Analisis Peneliti, 2017

Komponen green policy juga termasuk dalam kategori tidak siap jika dilihat dari karakteristik kawasan industri TerasMojosongo berdasarkan komponenkomponen kawasan green industry. Kebijakan merupakan payung hukum dan dasar penyelenggaraan segala kegiatana di dalam kawasan, sehingga keberadaannya merupakan keadaan mutlak bagi suatu kawasan (ULI, 1975). Kawasan industri Teras-Mojosongo sendiri belum memiliki dokumen rencana dasar yaitu masterplan/rencana induk perindustrian kawasan sebagai payung hukum yang menjadi pedoman pelaksanaan kegiatan di kawasan. Keadaan ini disebabkan karena efek berantai belum adanya Rencana Induk Perindustrian Jawa Tengah dan Rencana Induk Perindustrian Kabupaten Boyolali. Karena rencana pada tingkatan atas yang digunakan sebagai acuan belum ada, Pemerintah Kabupaten Boyolali juga belum mampu mengadakan kegiatan penyusunan Rencana Induk Perindustrian Kawasan Industri Teras-Mojosongo.

\subsection{Tingkat Kesiapan Kawasan Industri Teras Mojosongo sebagai Kawasan Green Industry}

Mengacu pada penilaian karakteristik kesiapan dapat diketahui karakteristik green plan memiliki nilai 2 (siap), karakteristik green process memiliki nilai 2 (siap), karakteristik green mnagement memiliki nilai 1 (tidak siap), dan karakteristik green process memiliki nilai 1 (tidak siap). Dan nilai total kesiapan setelah dikalikan bobot adalah 1,5. Untuk mengetahui tingkat kesiapan maka dilakukan perhitungan presentase kesiapan sebagai berikut :

Presentase kesiapan $=\frac{\text { total nilai kesiapan }}{(\text { total nilai tertinggi })} \times 100 \%$

Presentase nilai $=\frac{1,5}{(2)} \times 100 \%$

Presentase nilai $=75 \%$

Berdasarkan karakteristik kawasan industri Teras-Mojosongo terkait komponen-komponen kawasan green industry yang meliputi green plan, green process, green management, dan green policy, diketahui bahwa kesiapan kawasan industri Teras-Mojongongo Kabupaten Boyolali dalam penerapan konsep kawasan green industry secara keseluruhan termasuk ke dalam kategori mendekati siap.

Permasalahan utama yang terlihat dari kesiapan kawasan industri TerasMojosongo dalam menerapkan konsep kawasan green industry adalah dari sisi manajemen, dimana belum ada manajemen pengelola khusus yang berwenang mengelola kawasan industri Teras-Mojosongo secara keseluruhan. Adanya karakteristik kawasan industri Teras-Mojosongo yang belum memenuhi komponen-komponen kawasan green industry menunjukan bahwa Pemerintah Kabupaten Boyolali sebagai pihak yang saat ini memegang wewenang akan 
pengelolaan kawasan belum mampu memaksimalkan potensi yang dimiliki kawasan terkait penerapan konsep kawasan green industry. Dengan belum seluruh karakteristik kawasan terkait komponen-komponen kawasan green industry terpenuhi oleh kawasan industri Teras-Mojosongo, hal ini akan berpengaruh dalam rencana penerapan konsep kawasan green industry kedepannya.

\section{KESIMPULAN}

Kesimpulan yang didapatkan baik selama penelitian berlangsung ataupun hasil dari penelitian, serta saran baik untuk hasil penelitian serta penelitian selanjutnya adalah sebagai berikut.

\subsection{Kesimpulan}

Penelitian tingkat kesiapan kawasan industri Teras-Mojosongo sebgaai kawasan green industry ini selama proses penelitian dan berdasarkan analisis menemukan banyak hal dan dapat ditarik beberapa kesimpulan sebagai berikut :

a. Komponen green plan pada penelitian ini termasuk kategori siap dimana telah terdapat rencana terkait rencana yang mengatur kegiatan industri hijau dikawasan, infrastruktur penunjang industri hijau maupun rencana yang mengatur pengembangan komunitas hijau, walaupun tidak dalam satu dokumen rencana.

b. Komponen green process pada penelitian ini termasuk dalam kategori siap. Hal ini ditunjukan dengan masih dimungkinkannya diadakan pembangunan pada lahan kawasan dengan tetap mengoptimalkan proporsi lahan ideal. Selain itu infrastruktur kawasan, meliputi sarana, prasarana dan transportasi, juga telah tersedia serta mendukung konsep kawasan industri hijau yang ada.

c. Komponen green management pada penelitian ini termasuk dalam kategori tidak siap. Hal ini disebabkan belum tersedianya manajemen yang khusus mengelola kawasan sehingga kegiatan pengelolaan kawasan tidak sesuai dengan fungsi manajemen serta tidak ada kesatuan pemikiran antara pemerintah maupun pihak perusahaan industri dalam mencapai tujuan kawasan.

d. Komponen green policy pada penelitian ini termasuk dalam kategori tidak siap. Dimana masih belum tersedia peraturan daerah maupun surat keputusan Bupati Boyolali yang mengatur teknis pelaksanaan kegiatan di kawasan. Hal ini dikarenakan belum adanya rencana induk kawasan yang digunakan sebagai rujukan dalam merumuskan peraturan teknis.

e. Karakteristik kawasan industri TerasMojosongo telah sesuai dengan komponen-komponen kawasan green industry sehingga dapat disimpulkan bahwa kawasan industri TerasMojosongo memiliki potensi dalam pengembangan konsep kawasan green industry.

f. Tingkat kesiapan kawasan industri Teras-Mojosongo sebagai kawasan green industry masih dalah tahap mendekati siap sehingga kawasan masih perlu melakukan pengembangan pada beberapa karakteritis kawasan sesuai komponen kawasan green industry.

g. Belum adanya pengelola khusus kawasan green industry menyebabkan pengembangan konsep kawasan green industry belum maksimal karena tidak ada pihak yang menjembatani berbagai stakeholder dalam pengembangan kawasan sehingga potensi yang ada belum mampu dimanfaatkan secara maksimal.

h. Belum dirumuskannya rencana induk pengembangan industri kawasan menyebabkan Pemerintah Kabupaten Boyolali belum mampu membentuk peraturan daerah yang mengatur teknis pelaksanaan kegiatan di kawasan sehingga kawasan belum 
memiliki payung hukum yang lengkap dalam pelaksanaan kegiatannya.

\subsection{Saran}

Saran yang dapat peneliti sampaiakan setalah melakukan proses penelitian ini antara lain sebagai berikut :

a. Perlu adanya manajemen pengelola khusus kawasan industri TerasMojosongo sehingga pengelolaan kawasan lebih terstruktur dan maksimal.

b. Peningkatan karakteristik kawasan industri Teras-Mojosongo terkait komponen kawasan green industry perlu terus dilakukan sehingga suatu saat kesiapan kawasan dalam menerapkan konsep kawasan green industry dapat mencapai tahap siap sempurna.

c. Untuk penelitian selanjutnya dapat membuat alternatif sistem pengumpulan data lain sehingga dalam mengidentifikasi karakteristik kawasan dapat lebih mendetail.

\section{REFERENSI}

Basyaib. 2006. Teori Pembuat Keputusan. Yogyakarta: Andi Offset

Brugmann, J. 1999. Is There A Method In Our Measurement? The Use Of Indicators In Local Sustainable Development Planning. London: Earthscan.

Joga, Nirwono. 2013. Gerakan Kota Hijau. Jakarta: Gramedia Pustaka Utama

Joga, Nirwono. 2013. Greenesia. Jakarta: Gramedia Pustaka Utama.

Kementerian Pekerjaan Umum. 2011. Program Pengembangan Kota Hijau (P2KH): Panduan Pelaksanaan 2011. Direktorat Jenderal Penataan Ruang

Lu S., Huang M., Su P., Tseng K. and Chen F. 2013. Development strategy of green energy industry for Taipei $-A$ modern medium sized city. Energy Policy. 62, 484-492
Meadows, D. 1999. Indicator And Information System For Sustainable Cities. London: Eartscan.

Peraturan Menteri Perindustrian Nomor: 05/M-IND/PER/1?2011 tentang Program Penganugrahan Penghargaaan Industri Hijau.

Urban Land Institute. 1975. Business Park and Industrial Development Handbook. Washington D.C: Urban Land Institute.

www.kemenperin.go.id. Diakses pada tanggal 26 September 2016. Pukul $20.45 \mathrm{WIB}$.

www.dictionarybusiness.com/definition/ readiness.html. Diakses pada tanggal 15 Oktober 2016. Pukul 11.35 WIB.

Zhang, Yongli. 2016. China's Eco-City Construction. Cina. 

